\title{
The role of PI3K-mediated AMPA receptor changes in post-conditioning of propofol in brain protection
}

Chenxu Wang ${ }^{1} \mathbb{B}^{0}$, Ying Wei ${ }^{2}$, Yuan Yuan ${ }^{1}$, Yonghao Yu ${ }^{1}$, Keliang Xie ${ }^{1}$, Beibei Dong ${ }^{1}$, Yuan Shi $^{1}$ and Guolin Wang ${ }^{1 *}$

\begin{abstract}
Background: We aimed to study the role of amino-3-hydroxy-5-methylisoxazole-4-propionic acid receptor (AMPAR) glutamate receptor 2 (GluR2) subunit trafficking, and activity changes in short-term neuroprotection provided by propofol post-conditioning. We also aimed to determine the role of phosphoinositide-3-kinase (PI3K) in the regulation of these processes.
\end{abstract}

Methods: Rats underwent $1 \mathrm{~h}$ of focal cerebral ischemia followed by $23 \mathrm{~h}$ of reperfusion were randomly divided into 6 groups ( $n=36$ per group): sham- operation (S), ischemia-reperfusion (IR), propofol (P group, propofol $20 \mathrm{mg} / \mathrm{kg} / \mathrm{h}$ at the onset of reperfusion for $2 \mathrm{~h}$ after $60 \mathrm{~min}$ of occlusion), and LY294002 (PI3K non-selective antagonist) + sham ( $L+S$, LY294002 of $1.5 \mathrm{mg} / \mathrm{kg}$ was infused 30 min before sham operation), $L Y 294002+$ ischemia-reperfusion ( $L+I R$, LY294002 of $1.5 \mathrm{mg} / \mathrm{kg}$ was infused 30 min before middle cerebral artery occlusion), $L Y 294002+I R+$ propofol $(L+P$, LY294002 of $1.5 \mathrm{mg} / \mathrm{kg}$ was infused 30 min before middle cerebral artery occlusion and propofol $20 \mathrm{mg} / \mathrm{kg} / \mathrm{h}$ at the onset of reperfusion for $2 \mathrm{~h}$ after 60 min of occlusion).

Results: Compared with group IR, rats in group P had significant lower neurologic defect scores and infarct volume. Additionally, consistent with enhanced expression of PI3K-AMPAR GluR2 subunit complex substances in ipsilateral hippocampus, GluR2 subunits showed increased levels in both the plasma and postsynaptic membranes of neurons, while pGluR2 expression was reduced in group P. Furthermore, LY294002, the PI3K non-selective antagonist, blocked those effects.

Conclusion: These observations demonstrated that propofol post-conditioning revealed acute neuroprotective role against transient MCAO in rats. The short-term neuroprotective effect was contributed by enhanced GluR2 subunits trafficking to membrane and postsynaptic membranes of neurons, as well as down-regulated the expression of pGluR2 in damaged hippocampus. Finally, the above-mentioned protective mechanism might be contributed by increased combination of PI3K to AMPAR GluR2 subunit, thus maintained the expression and activation of AMPAR GluR2 in the ipsilateral hippocampus.

Keywords: Propofol, Post-conditioning, Phosphoinositide-3-kinase (PI3K), Amino-3-hydroxy- 5-methylisoxazole-4propionic acid receptor (AMPAR), Ischemia-reperfusion injury, Rat

\footnotetext{
*Correspondence: wang_guolin@hotmail.com

${ }^{1}$ Department of Anesthesiology, Tianjin Institute of Anesthesiology, General Hospital of Tianjin Medical University, No. 154 Anshan Road, Heping District, Tianjin 300052, People's Republic of China

Full list of author information is available at the end of the article
}

(c) The Author(s) 2019. This article is distributed under the terms of the Creative Commons Attribution 4.0 International License (http://creativecommons.org/licenses/by/4.0/), which permits unrestricted use, distribution, and reproduction in any medium, provided you give appropriate credit to the original author(s) and the source, provide a link to the Creative Commons license, and indicate if changes were made. The Creative Commons Public Domain Dedication waiver (http://creativecommons.org/ publicdomain/zero/1.0/) applies to the data made available in this article, unless otherwise stated. 


\section{Background}

With the growing population aging, there is an associated increase in the number of perioperative cerebrovascular accidents, which seriously threatens patients' quality of life [1]. For patients presenting with a high risk of cerebrovascular diseases, choosing an appropriately safe and effective anesthetic is a highly important challenge for anesthesiologists. Taking advantage of reducing intracranial pressure and cerebral metabolic rate [2], the frequently used intravenous anesthetic, propofol, revealed its importance and potential use to such patients.

Prophase work found propofol has protective effect on rat brain from ischemia-reperfusion injury by reducing the volume of cerebral infarction, and alleviating both nerve injury and neuronal apoptosis [3]. We also studied and established the most appropriate dosage regimen for propofol $(20 \mathrm{mg} / \mathrm{kg} / \mathrm{h})$ for post-conditioning. The mechanism behind the protection remains a major obstacle in the context of our current research. The phosphoinositide-3-kinase (PI3K)/protein kinase B (Akt) pathway plays an important role in the process of cerebral ischemia and brain protection. In the transient global cerebral ischemia model of the rat [4], the activation of the PI3K/Akt pathway may delay neuronal death in the hippocampal CA1 region [5]. When the pathway is suppressed, it can lead to the increase of DNA fragments and the increase of apoptotic neurons. In our previous study, propofol post-conditioning enhanced expression of pAkt in $24 \mathrm{~h}$ after transient MCAO (middle cerebral artery occlusion) [3].

Some studies showed that ischemic brain injury was closely related to amino-3-hydroxy-5- methylisoxazole4-propionic acid receptors (AMPAR), a tetramer system including GluR1-4 [6-8]. The continual expression of GluR2 on the cytomembrane plays a significant role in the prevention and cure of delayed neuronal injury following cerebral ischemia, due largely to its effect on decreasing permeability to $\mathrm{Ca}^{2+}$ by AMPARs $[6,9]$. Propofol post-conditioning can maintain stable expression of GluR2 subunit in postsynaptic membranes, while the upstream regulatory mechanism has yet to be clarified. There are many molecular mechanisms and pathways that are putatively responsible for the up- or down-regulation of both subunits stability and AMPAR expression [10]. Arendt et al. [11]. concluded that the continuous low expression of PIP (3), which is the product of PI3K at the postsynaptic terminal, is necessary for stabilizing AMPARs. Additionally, Man et al. [12] determined that PI3K was key in stabilizing the migration of GluR2 in postsynaptic membranes during LTP, and did so by connecting GluR2 at the C-terminal. However, the relationship between PI3K and GluR2 during propofol induced acute post-conditioning remained ambiguous by now. Phosphorylation of GluR2 subunits at Ser880 is one of the regulatory factors of AMPA receptors membrane translocation [13].

The rats went through ischemia-reperfusion injury, and the recovery of blood-reperfusion will cause more serious injury to brain tissue. Then propofol was given after treatment, and the protective effect of propofol on brain in rats was investigated by experiment. The major focus of this study is to investigate the relationship between PI3K and GluR2 by co-immunoprecipitation, immunogold-silver staining, and Western Blotting during propofol post-conditioning. And we used LY294002, an inhibitor of PI3K, to understand the relationship between PI3K and GluR2.

\section{Methods}

\section{Animals}

In the experiment, we chose 216 Adult male SpragueDawley rats (250-280 g, provided by Tianjin Medical University), and we fed them comply with the Guide for the Care and Use of Laboratory Animals of Tianjin Medical University. All experimental operations were approved by the committee of experimental animals of Tianjin Medical University. The rats were fasting 1 day before operation, allowing free water. Rats were randomly divided into 6 groups: sham-operated group (Group S), the ischemia-reperfusion group (Group IR), and the propofol Post-conditioning group (Group P), the LY294002 group (Group L+S), the IR with LY294002 group (Group L + IR), and propofol with LY294002 group (Group L+P). LY294002 is a specific antagonist of PI3K, we used it $30 \mathrm{~min}$ before operation. Rats in Group S and $\mathrm{L}+\mathrm{S}$ underwent a sham operation, while in Group IR and Group L+IR exposed to ischemia for $1 \mathrm{~h}$ and reperfusion injury for $23 \mathrm{~h}$. By contrast, rats in Group P and Group L + P received propofol $20 \mathrm{mg} / \mathrm{kg} / \mathrm{h}$ immediately after reperfusion for $2 \mathrm{~h}$.

\section{Drugs}

Propofol (Diprivan ${ }^{\circledR}$ ) was purchased from Zeneca Company (London, UK), and was administered via femoral vein with a syringe pump (Beijing Slgo Medical Technology Development Co., Ltd., China) at a dose of $20 \mathrm{mg} /$ $\mathrm{kg} / \mathrm{h}$ for $2 \mathrm{~h}$. For the remaining groups, equal volumes of saline were similarly administered. LY294002 was purchased from Sigma Aldrich (St. Louis, MO, USA), and dissolved in $10 \%$ dimethyl sulfoxide (DMSO, Sigma) prior to use.

\section{Middle cerebral artery occlusion (MCAO)}

We used the intraluminal suture method for transient middle cerebral artery ischemia [14]. After the rats were anesthetized with thiobutabarbital $(100 \mathrm{mg} / \mathrm{kg})$, 
$1 \%$ lidocaine was given local anesthesia at the incision of the rat, we treated the nylon monofilament into the right internal carotid artery through external carotid artery. The origin of right middle cerebral artery was blocked by the monofilament, which was pushed forward 17-20 $\mathrm{mm}$ from the right common carotid artery bifurcation. While the monofilament was advanced less than $10 \mathrm{~mm}$ as sham operation. To make the reperfusion, after $1 \mathrm{~h}$ of ischemia, we pulled out the nylon thread for $10 \mathrm{~mm}$. At the moment of reperfusion, rats received a different infusion from the right femoral vein via a TCI injection pump, while the inhibitor groups received of LY294002 at a dose of $1.5 \mathrm{mg} / \mathrm{kg}$ via intraperitoneal injection for $30 \mathrm{~min}$ before reperfusion. The room temperature was kept at $25-28{ }^{\circ} \mathrm{C}$, while the rats' rectal temperature was maintained at $37.0 \pm 0.5{ }^{\circ} \mathrm{C}$ by using an electric incandescent lamp. We measured the blood pressure and arterial blood gases from polyethylene catheters inserted into the right femoral artery.

\section{Neurological deficits}

One researcher who was unaware (blinded) of the animal grouping did the nerve injury experiments at 11 and $23 \mathrm{~h}$ after reperfusion. The neurological deficits were assessed on modified neurological severity score (mNSS) [15], which was composed of motor, sensation, reflex and balance ability tests. Thus, rats were evaluated for various aspects to accurately reflect the extent of nerve function damage (Table 1).

\section{Measurement of cerebral infarction volume}

At $11 \mathrm{~h}$ and $23 \mathrm{~h}$ after reperfusion, we anesthetized the rats (pentobarbital at $130 \mathrm{mg} / \mathrm{kg}$ for intraperitoneal injection) and took out brains (6 rats at each time node in each group). The steps are as follows: first cut off the head with large scissors, quickly trimmed off the muscles around the occipital bone, then pried open the occipital bone with vascular forceps, and carefully pried open the parietal bone on both sides of the brain, detached it from

\section{Table 1 Detailed description of items forming the modified neurological severity score (mNSS)}

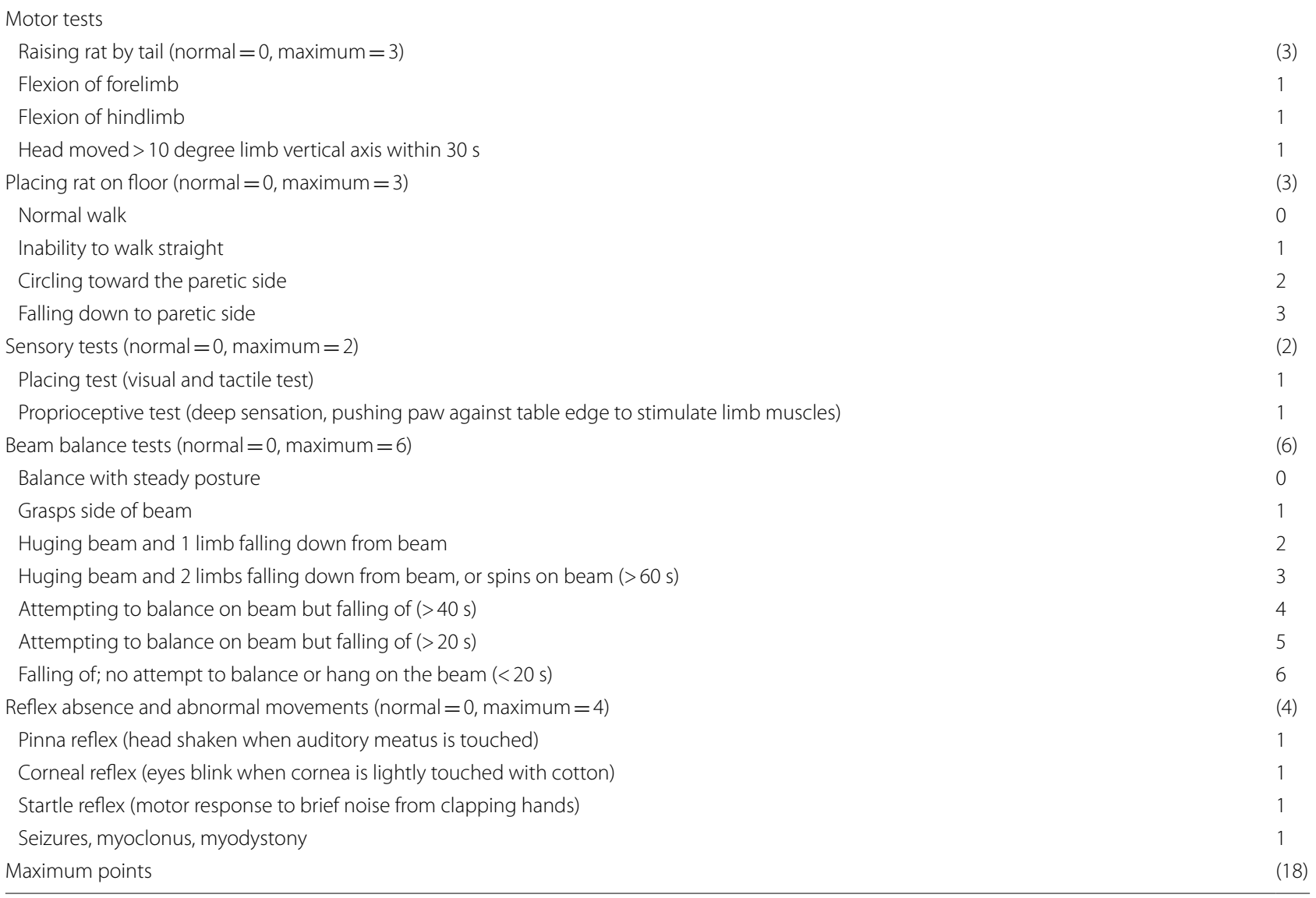

One point is given for an absent reflex tested or for the animal's inability to perform a task: 1-6 mild injury, 7-12 moderate injury, and 13-18 severe injury 
both sides of the brain with curved tweezers, and lifted the brain from the front. The brains were then cut into 6 coronal slices of $2 \mathrm{~mm}$. The slices were soaked in $2 \%$ triphenyltetrazolium chloride (TTC) light sheltered for $30 \mathrm{~min}$ at $37{ }^{\circ} \mathrm{C}$, and then fixed in $4 \%$ paraformaldehyde overnight. We took pictures of the back of each slice and analyzed the infarct size with AutoCAD. The cerebral ischemic volume was calculated by multiplying the area by the thickness $(2 \mathrm{~mm})$. To reduce the effects of edema, we adopted the following formula as previously described $[16,17]$ : Corrected Infarct Volume $=$ Contralateral Hemisphere Volume - (Ipsilateral Hemisphere Volume-Measured Infarct Volume).

\section{Tissue preparation}

The expression of GluR2 subunits and pGluR2 were investigated by Western blotting. We have previously confirmed the specificity of antibodies to GluR2, whereas the specificity to pGluR2 was tested in this study by Western blotting assay. Hippocampus of the ischemic hemisphere and containing GluR2 subunits were obtained $5 \mathrm{~h}$, $11 \mathrm{~h}$, and $23 \mathrm{~h}$ after MCAO. After being anesthetized by pentobarbital at $130 \mathrm{mg} / \mathrm{kg}$ for intraperitoneal injection, the rat's brain was removed and the right hemisphere was separated longitudinally. Then we cut off brain tissue, fed primarily by the anterior cerebral artery, approximately $2 \mathrm{~mm}$ from the midline. The injured hippocampus was exposed and stripped, and cut. Tissues $(\mathrm{n}=4-5$, in each group) were shredded and then proteins were isolated by lysis buffer $(50 \mathrm{mmol} / \mathrm{L}$ Tris- $\mathrm{HCl} \mathrm{pH}=6.8,0.5 \%$ sodium deoxycholate, $0.1 \%$ SDS, $150 \mathrm{mmol} / \mathrm{L} \mathrm{NaCl}, 0.5 \% \mathrm{NP}-40$, $5 \mathrm{mmol} / \mathrm{L}$ EDTA, protease inhibitor cocktail), followed by centrifugation $\left(2000 \mathrm{~g}, 5 \mathrm{~min}\right.$, at $\left.4{ }^{\circ} \mathrm{C}\right)$. When it comes to the GluR2 on the membrane, we used a eukaryotic membrane protein extraction reagent kit $\left(\mathrm{Mem}-\mathrm{PER}^{\mathrm{TM}}\right.$ Eukaryotic Membrane Protein Extraction ReagentKit, Pierce Biotechnology, Rockford, IL, USA)to extract GluR2 located on membrane from the total GluRs. The right hippocampus was sliced up and made tissue grinder with TBS. The homogenate was centrifuged and as the instructions of kits indicated incubated with reagent $\mathrm{A}$, $\mathrm{B}$, and $\mathrm{C}$ sequentially (Mem-PER ${ }^{\mathrm{TM}}$ Eukaryotic Membrane Protein Extraction ReagentKit, Pierce Biotechnology, Rockford, IL, USA). After centrifuge, tissues would be isolated the hydrophobic fraction, among which the hydrophilic phase was what we need and the majority of membrane protein would be in the lower hydrophobic fraction. A commercial BCA Protein Assay reagent kit (Pierce, Rockford, IL, USA) was used to measure total and membrane protein concentrations.

\section{Western blot and co-immunoprecipitation}

The protein used for co-immunoprecipitation was freshly prepared while that used for Western blot was stored at $-80{ }^{\circ} \mathrm{C}$ until assayed. The PI3K-GluR2 complex was detected by co-immunoprecipitation. As Yang et al. described [18], protein solution was centrifuged, and the supernatants were selected by protein A/G beads (Santa Cruz Biotechnology, Santa Cruz, CA, USA) and immunoprecipitated overnight at $4{ }^{\circ} \mathrm{C}$ with anti-GluR2 (rabbit monoclonal; Millipore) antibodies. The complex substance was precipitated in on protein $\mathrm{A} / \mathrm{G}$ beads and washed in IP buffer for 5 times (IP buffer: $50 \mathrm{mM}$ Tris$\mathrm{HCl}, \mathrm{pH}=7.4,0.5 \%$ Nonidet $\mathrm{P}-40,300 \mathrm{mM} \mathrm{NaCl}$ ), followed by cold PBS at $4{ }^{\circ} \mathrm{C}$ once. Both the precipitate and protein lysates were boiled in Laemmli buffer at $95{ }^{\circ} \mathrm{C}$ for $5 \mathrm{~min}$ (Laemmli buffer: $60 \mathrm{mM}$ Tris-HCl, $\mathrm{pH}=6.8$, $10 \%$ glycerol, $2 \%$ SDS, $5 \% \beta$-mercaptoethanol, and $0.01 \%$ bromphenol blue) for Western blot analysis. We used the procedures outlined by Adotevi et al. [19] whereupon the proteins were separated by SDS-PAGE and then transferred onto PVDF membranes (Millipore). Specified antibodies were dissolved in TBST buffer $(100 \mathrm{mM}$ Tris- $\mathrm{HCl}, \mathrm{pH}=7.5,150 \mathrm{mM} \mathrm{NaCl}, 0.1 \%$ Tween 20) with $5 \%$ skimmed milk powder (Tesco) and ECL (GE Healthcare) for detecting. The antibodies included anti-GluR2 (1:1000, monoclonal, CST, USA) antibody for measuring the expression of total GluR2 $(110 \mathrm{kDa})$, anti-pGluR2 (1:1000, monoclonal, Abcam, USA) antibody for detecting the expression of pGluR2, and anti-PI3K (1:1500, monoclonal, CST, USA) antibody for investigating the expression of the PI3K-GluR2 complex $(85 \mathrm{kDa})$ in the immunoprecipitation assay. Blots were washed and then incubated with goat anti-rabbit IgG secondary antibody conjugated to horseradish peroxidase (1:5000, Santa Cruz Biotechnology, CA, USA) for $1 \mathrm{~h}$ at room temperature and signals were displayed by ECL (Amersham, Buckinghamshire, UK). Quantitative analysis of the band densities was performed by Quantity One Analyzer 4.5 (BioRad Laboratories, CA) in a blinded fashion, semiquantitative determination of the levels of both GluR2 and pGluR2 were reflected by the percentages of light densities as compared with $\beta$-actin, while the complex of PI3K-GluR2 were compared with that of GluR2.

\section{Immunogold-silver staining and electron microscope}

Following $23 \mathrm{~h}$ of reperfusion, the animals in Group $\mathrm{S}, \mathrm{IR}, \mathrm{P}$ and $\mathrm{L}+\mathrm{P}(\mathrm{n}=6$ in each group) were anesthetized with pentobarbital at $130 \mathrm{mg} / \mathrm{kg}$ and injected with 1000 IU heparin into the aorta. Thereafter, and according to the procedures outlined by Sonomura et al. [20], rats 
were perfused with $200 \mathrm{ml}$ of saline solution followed by $100 \mathrm{ml}$ of fixative solution supplemented with $2 \%$ paraformaldehyde (Sigma, USA) and 3.8\% acryl aldehyde (Sigma, USA) in $0.1 \mathrm{M}$ PBS, $\mathrm{pH}=7.4$ through the left ventricle and at room temperature. Next, the brain was removed and immersed overnight in $2 \%$ paraformaldehyde fixative solution. The right hemisphere of the brain enabled coronal sections $(30-40 \mu \mathrm{m})$ to be obtained using a vibratome (Leica, Germany), which were then immersed in $1 \%$ sodium borohydride in $0.1 \mathrm{M}$ PBS for $30 \mathrm{~min}$. Tissue sections were then rinsed in $0.1 \mathrm{M}$ PBS, followed by $0.1 \mathrm{M}$ Tris-buffered saline (TBS; $\mathrm{pH}=7.6$ ) and blocked in $1 \%$ bovine serum albumin (BSA) in TBS before incubation in respective primary antibodies.

Tissue slices were incubated overnight at $4{ }^{\circ} \mathrm{C}$ in GluR2 subunit primary antibody (1:500, monoclonal, Abcam, USA) in $0.1 \mathrm{M}$ TBS with $0.1 \%$ BSA. For immunogold-silver staining of GluR2 trafficking, slices were incubated in $1 \mathrm{nM}$ gold-conjugated goat anti-rabbit IgG (1:50, Amersham Corp., Amersham, England), and enhanced staining with a silver enhancement kit (Amersham Corp.), then fixed in 2\% glutaraldehyde in PBS. The ischemic was collected on copper mesh grids and then sliced into ultrathin sections hippocampus, and photographed by a Morgagni 268 (FEI Company, Hillsboro, Oregon) digital electron microscope. Adobe Photoshop (Adobe, San Jose, $\mathrm{CA}$ ) was used to regulate brightness and contrast and to form the final images. 9 neurons and 5 cynapsis around were chosen randomly and the percentages of GluR2 subunits in the postsynaptic membrane were calculated by counting the positive granules in both cytoplasm and plasma membrane to reflect the trafficking of GluR2 subunits.

\section{Statistical analyses}

Data are presented as mean \pm SEM and analyzed by SPSS version 18.0 statistical software. Infarct volume, coimmunoprecipitation, and Western blot data were analyzed by multivariate analysis of variance (MANOVA), while mNSS scores were analyzed by repeated measures analysis of variance (ANOVA). Statistical analyses of immunogold-silver staining were performed using oneway ANOVA. The individual comparisons of means were analyzed by post hoc LSD tests. All values were considered statistically significant for alpha values of $\mathrm{P}<0.05$.

\section{Results}

\section{Physiological variables of rats}

We monitored physiological parameters that consisted of mean arterial blood pressure, glucose, and blood gas analysis during the experiment (done at three time-points: 10 min before occlusion, $1 \mathrm{~h}$ after occlusion, and $1 \mathrm{~h}$ after reperfusion). No statistical differences were observed in these physiological parameters and blood gas analysis among the rats in different groups (the results of blood gas were showed in Table 2). There were no adverse events such as anoxia and asphyxia caused by operation and propofol infusion.

\section{Propofol post-conditioning of neurological deficit after IR injury in rats}

In the following $23 \mathrm{~h}$ of reperfusion after ischemic injury, we measured the modified neurological severity score (mNSS). A lower score showed rats had lower neurological defects from IR injury $(\mathrm{P}<0.0001$ at both $11 \mathrm{~h}$ and $23 \mathrm{~h}$ compared with Group S), and presented with more improved outcome by propofol post-conditioning. The statistical data showed that propofol at the dose of $20 \mathrm{mg} /$ $\mathrm{kg} / \mathrm{h}$ infusion for $2 \mathrm{~h}$ significantly decreased the neurological deficit as compared with group IR at both $11 \mathrm{~h}$ $(\mathrm{P}=0.035)$ and $23 \mathrm{~h}(\mathrm{P}=0.042)$ after IR injury. Administration of LY294002 partly but significantly reversed the decrease in scores induced by propofol $(\mathrm{P}=0.015$ at $11 \mathrm{~h}$, and $\mathrm{P}=0.020$ at $23 \mathrm{~h}$ after IR injury, Fig. 1).

\section{Propofol treatment on infarct volume in rats with IR injury}

The percentage of infarct size in brain was calculated by TTC staining of brain slices. All the groups presented infarct lesion, which differentially became gradually larger with the exception of Group $\mathrm{S}$ and $\mathrm{L}+\mathrm{S}$ at $23 \mathrm{~h}$ after IR injury. We found that the infarct volume at both time-points decreased significantly in group $\mathrm{P}$ as compared with group IR $(\mathrm{P}=0.12$ at $11 \mathrm{~h}$ and $\mathrm{P}=0.008$ at $23 \mathrm{~h}$ after IR injury). By contrast, pretreatment with LY294002 partly eliminated the protection induced by propofol $(\mathrm{P}=0.014$ at $11 \mathrm{~h}$ and $\mathrm{P}=0.016$ at $23 \mathrm{~h}$ as compared with group P, respectively, Fig. 2a, b).

\section{Propofol post-conditioning effect on the expression of the PI3K and GluR2 complex}

Co-immunoprecipitation analysis was to reveal the effect of propofol post-conditioning on co-expression of PI3K and GluR2 at $5 \mathrm{~h}, 11 \mathrm{~h}$ and $23 \mathrm{~h}$ after IR injury. Total GluR2 expression in the ischemic hippocampus was comparable in all groups after $23 \mathrm{~h}$ of reperfusion $(\mathrm{P}>0.05)$. Infusion of propofol for $2 \mathrm{~h}$ significantly increased the PI3K and GluR2 complex level in the ischemic hemicerebrum of rats as compared with the IR group $(\mathrm{P}<0.0001$, $\mathrm{P}<0.0001$, and $\mathrm{P}=0.001$ at each time-point). Administration of the PI3K inhibitor, LY294002 partly reversed the elevated levels of the complex $(\mathrm{P}=0.015, \mathrm{P}=0.011$, and $\mathrm{P}=0.023$ at each time-point) as compared group $\mathrm{P}$ (Fig. 3a, b). 


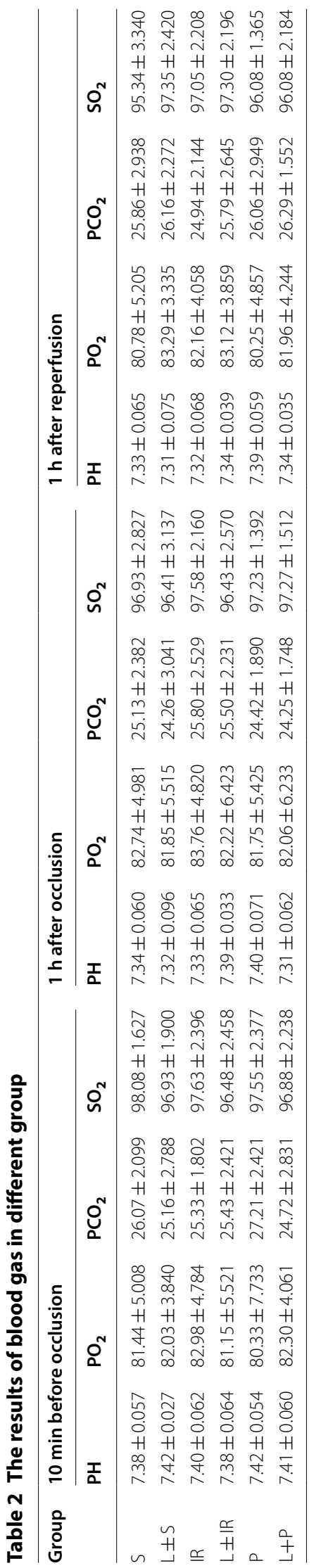




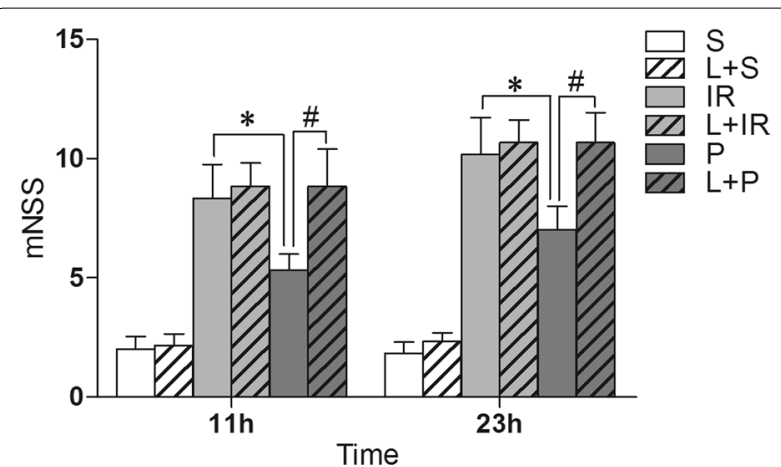

Fig. 1 Propofol post-conditioning reduced the behavior deficit. Behavior tests showed propofol post-conditioning significantly improved function outcome. The mNSS in groups received propofol post-conditioning is significantly less than that in IR Group both at $11 \mathrm{~h}(\mathrm{P}=0.035)$ and $23 \mathrm{~h}(\mathrm{P}=0.042)$ after IR injury. Administration of LY294002 partly but significantly reversed the decrease in scores induced by propofol $(P=0.015$ at $11 \mathrm{~h}$, and $\mathrm{P}=0.020$ at $23 \mathrm{~h}$ after IR injury). $\mathrm{n}=6$ for each group. S: sham-operated group; IR: P: propofol Post-cond group; L + S: sham-operated group; L+ IR: LY294002 + ischemia-reperfusion injury group; L + P: LY294002 + propofol Post-cond group. ${ }^{*} P<0.05$ vs Group IR; ${ }^{\# P}<0.05$ vs Group P

\section{Effect of propofol on trafficking of GluR2 subunits in IR injured rats}

We used antibody of GluR2 to detect the expression of membrane structure (M) and total (T) AMPA receptor GluR2 reflected by Western Blotting (Fig. 4a, b). The expression of total GluR2 were almost same in every group $(\mathrm{P}>0.05)$ while the membrane values had different levels. The distribution of GluR2 was described by the ratio of M/T compared with $S$ Group at each time point (Fig. 4a, b). Rats in the IR Group had significantly low GluR2 $\mathrm{M} / \mathrm{T}$ values compared with sham-operated rats $(\mathrm{P}<0.0001$ at every tome point), which means the IR injury caused the GluR2 subunits internalization to the cytoplasm from the membrane structure. The situation were changed when the rats were under the postconditioning of propofol, for which in Group P the ratio was significantly higher than that in IR Group $(\mathrm{P}=0.015$ at $5 \mathrm{~h}, \mathrm{P}<0.0001$ at $11 \mathrm{~h}$ and $23 \mathrm{~h}$ ). The changes of the distribution showed that propofol post-conditioning strengthened the GluR2 subunits located on the membrane structure in hippocampus. When the inhibitor of PI3K was administered, some of the membrane GluR2

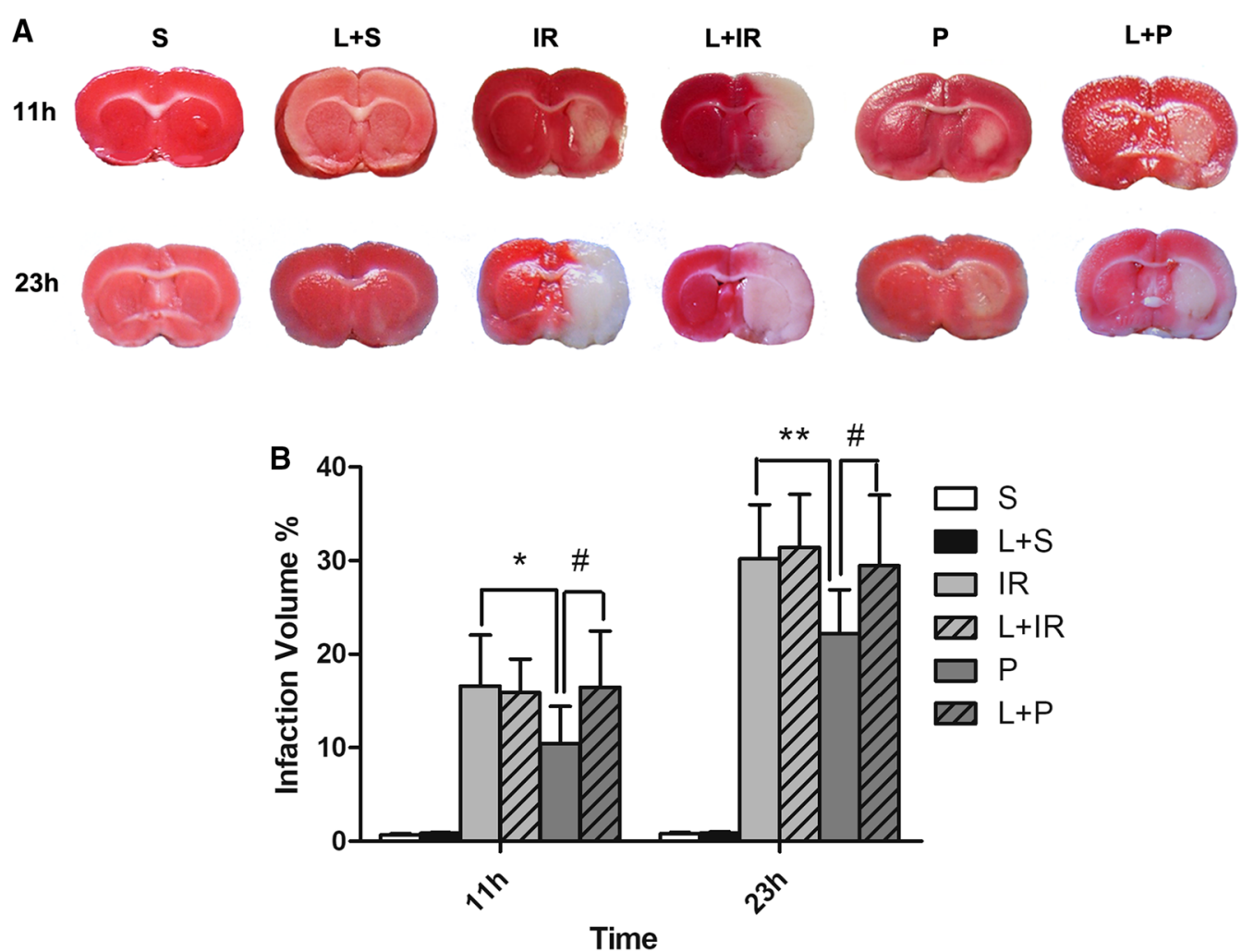

Fig. 2 Propofol post-conditioning mitigated the infarction injury. A Pictures of TTC staining in brain sections. B Statistical results of cerebral infarction volume in each group of rats. Infarcted area shown on TTC staining (white color) was prominent in the IR Group while decreased in propofol treated groups at two time points $(P=0.12$ at $11 \mathrm{~h}$ and $\mathrm{P}=0.008$ at $23 \mathrm{~h}$ after IR injury). By contrast, pretreatment with $L Y 294002$ partly eliminated the protection induced by propofol $(P=0.014$ at $11 \mathrm{~h}$ and $P=0.016$ at $23 \mathrm{~h}$ as compared with group $P$, respectively). $\mathrm{n}=6$ for each group. S: sham-operated group; IR: P: propofol Post-cond group; L+ S: sham-operated group; L+ IR: LY294002 + ischemia-reperfusion injury group; L+P: LY294002 + propofol Post-cond group.*P $<0.05$ vs Group IR; *P $<0.01$ vs Group IR; ${ }^{*} \mathrm{P}<0.05$ vs Group P 

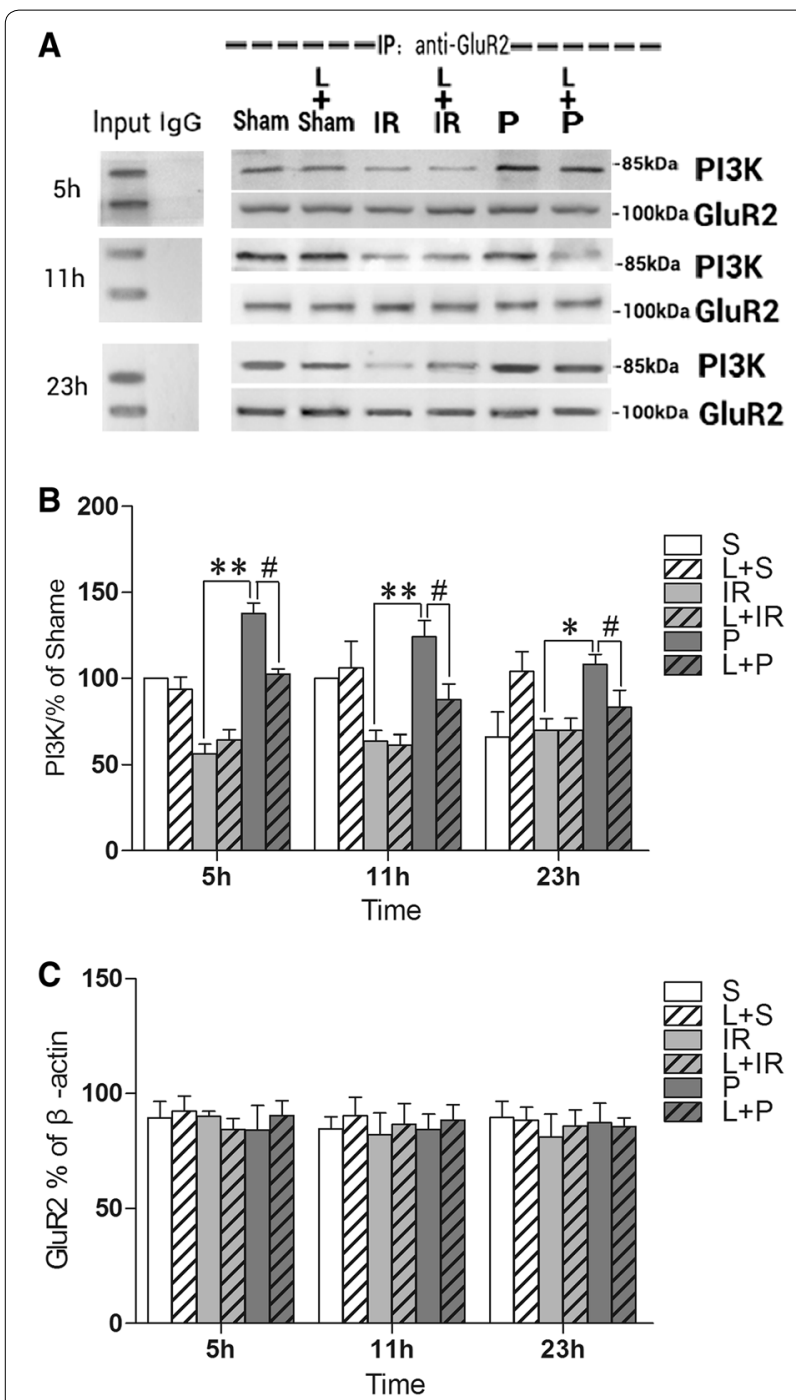

Fig. 3 Propofol post-conditioning enhanced the combination of GluR2 and PI3K. A The western blotting assay of PI3K-GluR2 complex. The tissue from ischemic hippocampus was incubated with antibody of GluR2. The complexes were collected on protein A/G beads. Anti-PI3K antibody was used for investigating the expression of PI3K-GluR2 complex in the immunoprecipitation at $85 \mathrm{kDa}$. Anti-GluR2 antibody was to detect the concentration of total GluR2 which reflected at $100 \mathrm{kDa}$. S: sham-operated group; IR: P: propofol Post-cond group; L+S: sham-operated group; L+ IR: LY294002 + ischemia-reperfusion injury group; L+P: LY294002 + propofol Post-cond group. B The statistical result of optical density was gathered and compared with Shame Group to get the results of complex. compared S Group, other groups at any time point had more expression of PI3K-GluR2 complex; while in Group P the complex containing was higher compared with Group IR $(P<0.0001, P<0.0001$, and $P=0.001$ at each time-point).: applied LY294002 depressed the trend which made by propofol ( $P=0.015, P=0.011$, and $P=0.023$ at each time-point). $n=6$ for each group. ${ }^{*} P<0.05$ vs Group IR; ${ }^{* *} P<0.01$ vs Group IR; ${ }^{\# P}<0.05$ vs Group P. C The expression of total GluR2. There were no significant differences in each group at each time point subunits moved to the cytoplasm and made the $\mathrm{M} / \mathrm{T}$ ratio lower compared with $\mathrm{P}$ Group $(\mathrm{P}=0.028$ at $5 \mathrm{~h}, \mathrm{P}=0.005$ at $11 \mathrm{~h}, \mathrm{P}=0.002$ at $23 \mathrm{~h}$ ). LY294002 might influence the distribution of GluR2, which means the PI3K might be the upstream of AMPA receptor GluR2 subunits. While the membrane structure in nerve cells was composed of cytomembrane, membranous organelles and cytoskeleton, only Western Blotting results can't explain the location of GluR2 at subcellular level. Then we observed the exact location from electron microscope pictures.

Electron microscopic photographs are used to describe subcellular localization of GluR2 subunits in the ischemic hippocampus of rats that underwent $1 \mathrm{~h}$ of ischemia and $23 \mathrm{~h}$ of reperfusion injury. Black deposits indicated goldsilver immunolabeling were easy to distinguished from the electron dense peroxidase reaction products. The diameters of the granules were almost $1.4 \mathrm{~nm}$ (as shown by the arrows in Fig. 5a). In each section, 9 neurons and 5 synapses were chosen randomly, and 5 sections were used to calculate the positive granules in both the cytoplasm and plasma membrane to reflect trafficking of GluR2 subunits in each hippocampus.

Semi-quantitative analysis was used to calculate the percentage of GluR2 subunits localized to the membrane of neurons in the cerebral hemispheres of rats subjected to IR injury and treated with or without propofol postconditioning or the inhibitor LY294002. In the rat of by sham operation, the GluR2 subunits were localized on both cytoplasmic membrane and intracellular compartments of neurons, and the majority located on plasma membrane (almost 14\%). When subjected to IR injury, the majority of GluR2 subunits were found localized in the plasmalemma and intracellular compartments, such as the mitochondria (Fig. 5a), and down-regulated on the cytoplasmic membrane or synapse/postsynaptic membrane. Additionally, the percentage of GluR2 subunits located in the postsynaptic membrane was $4.5 \%$ $(\mathrm{P}=0.007$ as compared with Group S). Propofol at a dose of $20 \mathrm{mg} / \mathrm{kg} / \mathrm{h}$ post-conditioning redistributed GluR2 to the postsynaptic membrane. This was especially evidents compared with Group IR ( $12.5 \%$ vs. $4.5 \%, \mathrm{P}=0.02$, Fig. 5b). Moreover, in Group L $+\mathrm{P}$, reduced frequencies of the GluR2 subunits were found in the postsynaptic membranes $(5.81 \%)$ as compared with that in Group P $(\mathrm{P}=0.046)$.

\section{The expression of pGluR2 during post-conditioning induced by propofol}

We measured the levels of pGluR2 in the ischemic hippocampus by Western blot assay. The results were reflected by the ratio of light densities relative to that of total GluR2. As compared with Group S, the rats in the 

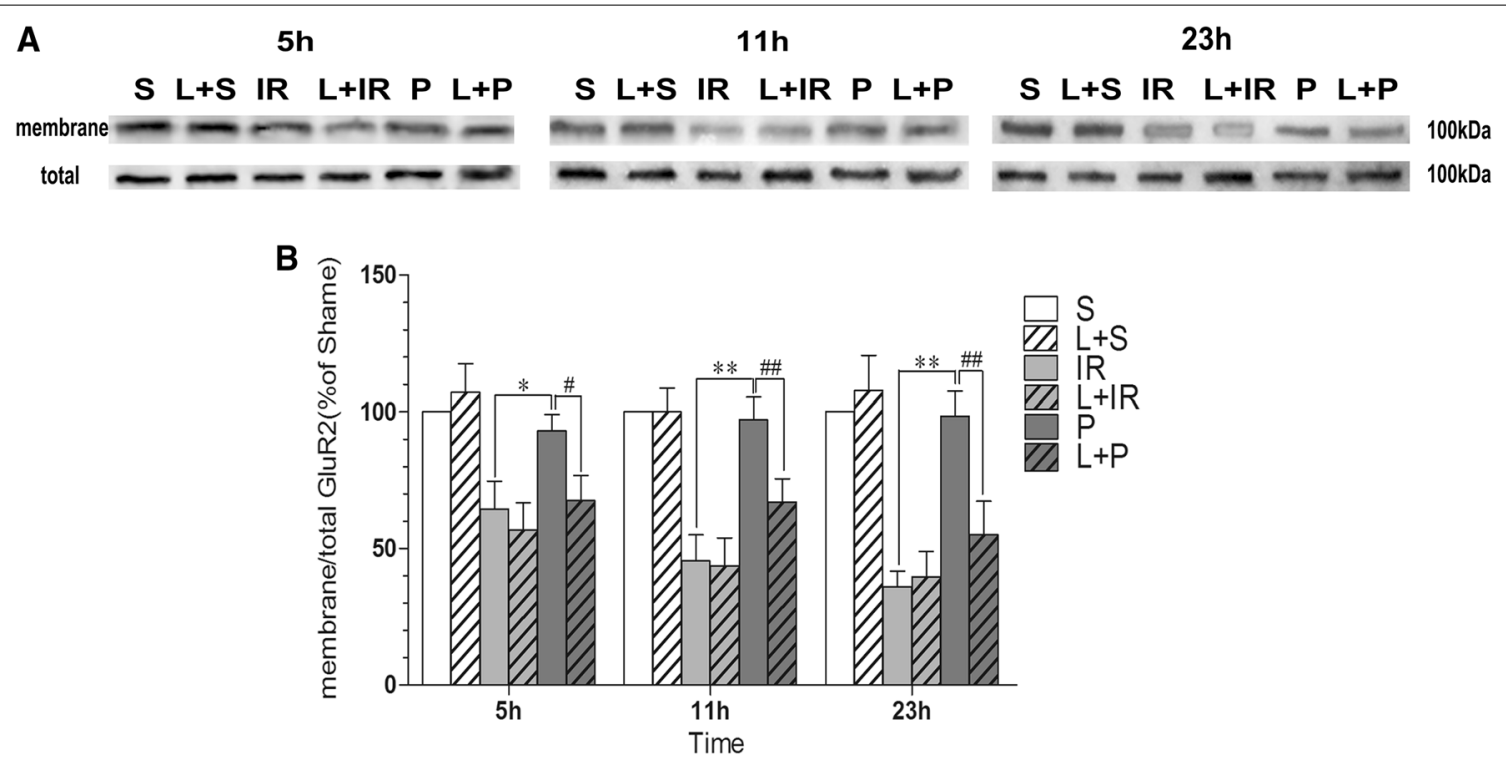

Fig. 4 Propofol post-conditioning promoted the expression of GluR2 on the membrane structure. A The tissue extracted by the membrane protein kit was reflected by Western Blotting with antibody of GluR2 subunit. In Group IR, most of the GluR2 located on the membrane structure, while in L+P Group the trafficking to membrane structure was weakened. S: sham-operated group; IR: P: propofol Post-cond group; L+S: sham-operated group; L+IR: LY294002 + ischemia-reperfusion injury group; L+ P: LY294002 + propofol Post-cond group. B We measured the concentration of GluR2 subunits located on membrane with the proportion of M/T (membrane/total) and found that the proportion in Sham Group did not change much, so the results in other groups were reflected by the comparison with Sham group. Compared with Group IR the GluR2 moved to the membrane structure $(P=0.015$ at $5 \mathrm{~h}, \mathrm{P}<0.0001$ at $11 \mathrm{~h}$ and $23 \mathrm{~h})$. Compared with Group $P$, the ratio of $M / T$ in Group $L+P$ was lower $(P=0.028$ at 5 h, $P=0.005$ at 11 h, $P=0.002$ at 23 h). $n=6$ for each group. ${ }^{*} P<0.05$ vs Group IR; ${ }^{*} P<0.01$ vs Group IR; $P<0.05$ vs Group $P$; $\# \#<0.05$ vs Group $P$

other groups expressed more pGluR2 $(\mathrm{P}<0.01)$, which meant that IR injury might have provoked the phosphorylation of GluR2. In Group P, the extent of phosphorylation was attenuated by propofol post-conditioning $(20 \mathrm{mg} / \mathrm{kg} / \mathrm{h})$ as compared with that in Group IR over the following $23 \mathrm{~h}(\mathrm{P}=0.0001$ at each time-point). Additionally, LY294002 played an important role in promoting significant accumulation of pGluR2 as compared that seen in Group $\mathrm{P}(\mathrm{P}=0.010, \mathrm{P}=0.002$, and $\mathrm{P}=0.016$ at each time-point). However, the expression of pGluR2 at different time-points was no different between Groups IR and $\mathrm{L}+\mathrm{IR}(\mathrm{P}>0.05$, Fig. 6a, b).

\section{Discussion}

This research clarified that propofol $(20 \mathrm{mg} / \mathrm{kg} / \mathrm{h})$ postconditioning for $2 \mathrm{~h}$ at the onset of reperfusion (ischemia for $1 \mathrm{~h}$ ) can provide acute $(23 \mathrm{~h})$ neuroprotection against IR injury induced by MCAO in rats. Both histological and neurological data can support experimental conclusions, including a reduction in the brain infarct volume and attenuation of the neurological deficit. We also showed that propofol $(20 \mathrm{mg} / \mathrm{kg} / \mathrm{h})$ for $2 \mathrm{~h}$ postconditioning differentially regulated the co-expression of PI3K and GluR2 subunits, since a marked increase in the PI3K-GluR2 complex was observed in the ischemic hippocampus, which contributed to the trafficking of
GluR2 subunits in postsynaptic membrane (as observed by Western blotting assay and electron microscopy staining). The down-regulated level of phosphorylated GluR2 subunits was also one of the results induced by the coexpression of PI3K and GluR2 and contributed to propofol post-conditioning.

\section{The GluR2 subunits and AMPA receptors}

AMPA receptors (AMPAR) are involved in a lot of physiological processes in mature or developing brain, including synaptic plasticity, learning and memory formation [21, 22]. AMPARs mediate almost $70 \%$ of the excitatory synapse transmissions in CNS [23]. Additionally, the nerve damage and pathogenesis of neuronal loss caused by cerebral ischemia is also mediated by AMPAR $[24,25]$. Some experiments have indicated that AMPAR can lead to the increase of intracellular $\mathrm{Ca}^{2+}$ and $\mathrm{Zn}^{2+}$ concentration, resulting in cytotoxic changes and nerve injury [26-28], with subsequent activation of diverse downstream cell death signals. Although the underlining mechanisms are not fully clear, it is suggested that $\mathrm{Ca}^{2+}$-permeability of AMPARs varies depending on whether the GluR2 subunits are present within the AMPARs [29]. AMPARs are tetrameric assemblies of different combinations of four homologous subunits designated GluR1-GluR4. 


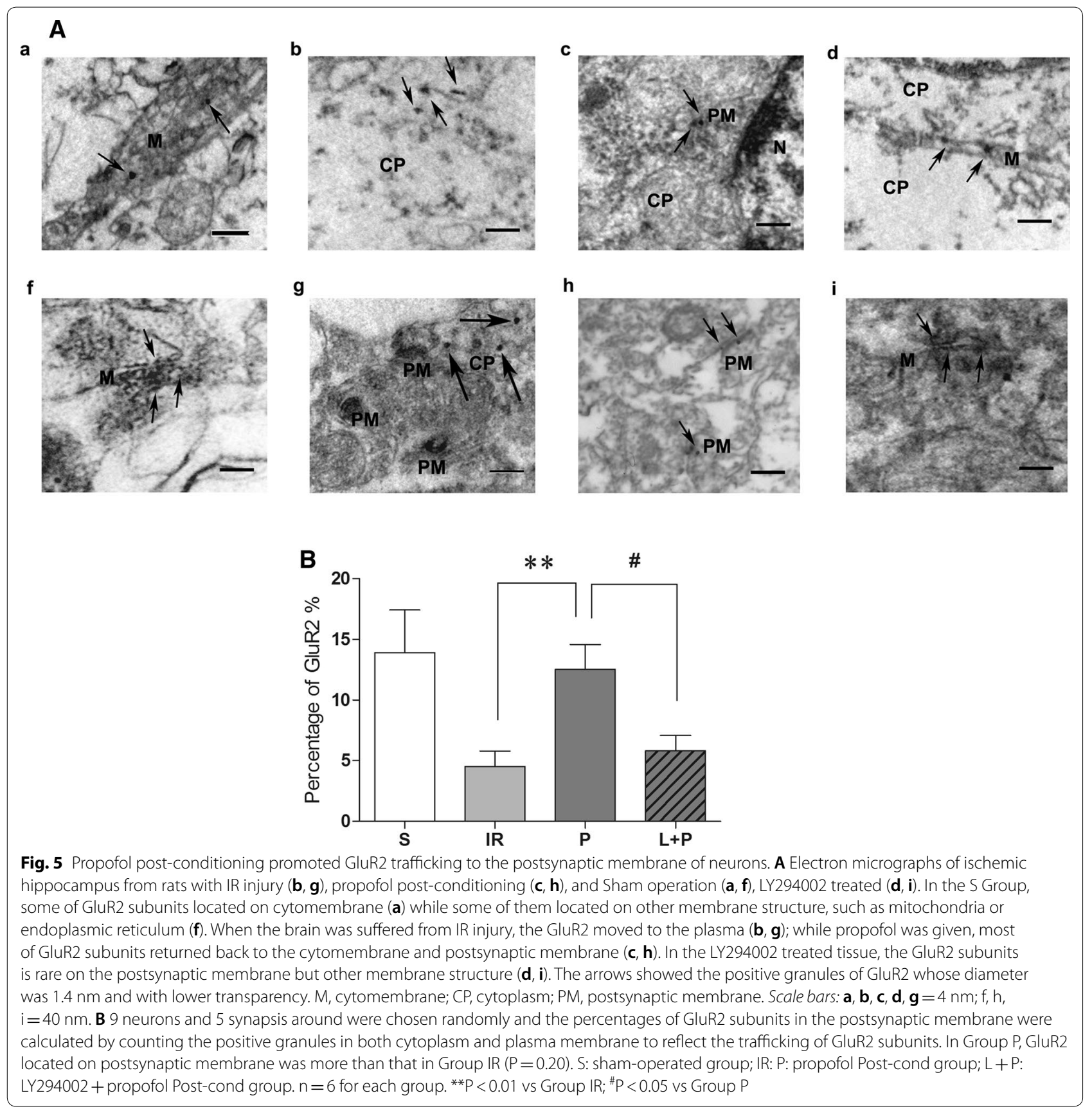

The ion selectivity of AMPARs containing GluR2 subunits is dominant over other subunits. It is now clear that there exist AMPARs without GluR2 subunits exhibiting considerable $\mathrm{Ca}^{2+}$ permeability, but when they contain GluR2 subunits the permeability to $\mathrm{Ca}^{2+}$ becomes very scarce $[27,29,30]$. The internalization of GluR2 subunits may lead to the influx of $\mathrm{Ca}^{2+}$, which may lead to nerve damage in the ischemic area
$[30,31]$. And the changes in the distribution of GluR2 subunits can cause activation of a caspase-dependent apoptotic pathway [24]. Thus, stabilization of GluR2 plays an important role in prevention and cure of neuronal injury. However, the changes to the trafficking and activity of GluR2 subunits are still indeterminate, as are the mechanisms responsible for upstream regulation. 
A

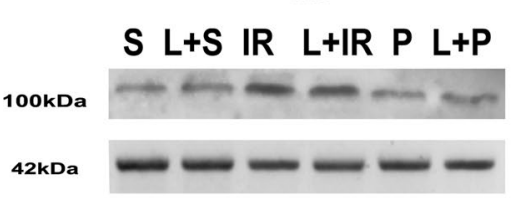

$11 \mathrm{~h}$

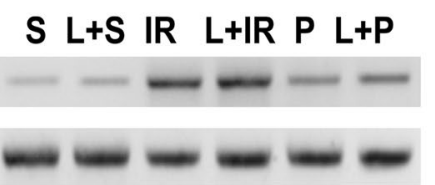

$23 \mathrm{~h}$

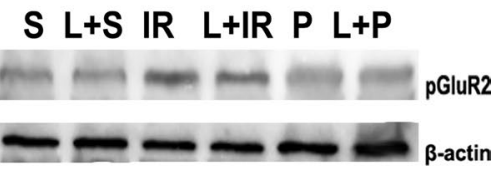

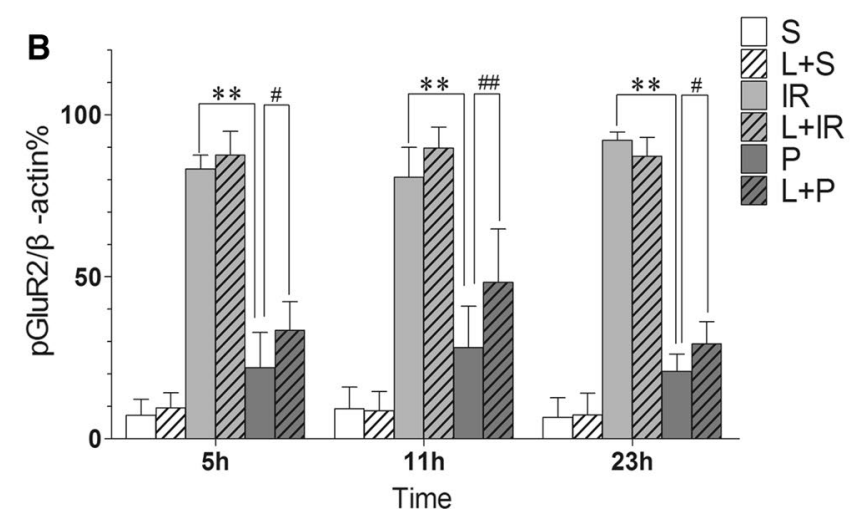

Fig. 6 The expression of pGluR2 during post-conditioning induced by propofol. A The phosphorylation level of GluR2 after propofol post-conditioning. The tissue from Ischemic hippocampus was incubated with anti-pGluR2 antibody (S880) and concentration of pGluR2 was detected by Western Blot (100 kDa). S: sham-operated group; IR: P: propofol Post-cond group; $L+S$ : sham-operated group; $L+I R$ : LY294002 + ischemia-reperfusion injury group; L + P:LY294002 + propofol Post-cond group. B Compared with Group S, the injury brain would express more pGluR2; when compared with Group IR, it was at lower level in Group P; More noteworthy is that inhibitor of PI3K could up-regulate the level which was reduced by propofol. $n=6$ for each group. ${ }^{* *} P<0.01$ vs Group IR; $\#$ P 0.05 vs Group P; $\#$ P $<0.05$ vs Group P

\section{The trafficking of GluR2 subunit-containing AMPAR}

The movement of AMPAR between cell membrane and cytoplasm is a dynamic process and is mediated by a variety of proteins [32] that always bind to GluR2 and GluR3 subunits, thereby mediating the long-term potentiation (LTP) and long-term depression (LTD) [33]. Studies by Man et al. [12] further revealed that GluR2-associated PI3K activity mediated AMPAR trafficking. This model showed that, $\mathrm{Ca}^{2+}$ influx via activated NMDAR. High concentration of $\mathrm{Ca}^{2+}$ results in activation of a GluR2-associated PI3K and increased expression of membrane bound phosphoinositide-3,4,5trisphosphate (PtdIns-3P), which will facilitate membrane targeting of AMPARs. Investigating the changes of GluR2 was one of our research objectives, as the Western Blotting results showed that the total GluR2 subunits did not change much after IR injury and propofol post-conditioning, while on the membrane structures the expression of GluR2 was up-regulated, the trafficking of GluR2 deserved investigation. Eukaryotic membrane protein extraction kit selected the protein on membrane, but GluR2 might located on diverse intracellular organelles, such as lysosomes, mitochondria, and Golgi Complexes. A great deal of the subcellular structures are membranous despite the protein on membrane was extracted by cross-linking assay, the precise location of GluR2 still need intuitive images to reveal. So immunogold-silver staining was for the further study of the GluR2 trafficking on the postsynaptic membrane. At $23 \mathrm{~h}$ after reperfusion, the expression of GluR2 subunit changed obviously on the membrane, so we did only one time point of electron microscopic observation, and we chose only four groups of animals for comparison. The rest of the time points and animal groups need to be discussed in further experiments. As we showed in our current study, propofol post-conditioning might stabilize the GluR2 subunits expression on postsynaptic membrane rather than other membrane structure, which would depress the $\mathrm{Ca}^{2+}$-permeability of AMPARs with GluR2 subunits.

\section{The phosphorylation of GluR2 subunits}

AMPAR GluR2 subunits contain postsynaptic density protein 95/discsslarge/zon occlusens-1 (PDZ) domain, which can be phosphorylated at serine 880 (S880) [34] and is responsible for the trafficking and activity of AMPARs. It does so by disrupting interactions of GluR2 subunits with its synaptic anchoring proteins, removing synaptic GluR2 subunits, and mediating some form of activity-dependent synaptic depression [35]. In addition, phosphorylation of S880 in synaptic GluR2 subunits can induce the redistribution of AMPARs away from the synapses, which will cause receptor endocytosis, as during 
long-term depression (LTD). In this study, the majority of AMPARs with phosphorylating GluR2 subunits remained settling on the postsynaptic membrane and did not co-traffick with the endocytosed receptor population. By contrast, the non-phosphorylated receptors co-trafficked with the endocytosed receptors. Phosphorylation of $\mathrm{S} 880$ on GluR2 subunits is also closely related to brain degenerative diseases as well as the trafficking of GluR2 subunits. Studies that have focused on the pathogenesis of Alzheimer's disease have discovered that amyloid- $\beta$ protein $(A \beta)$ increases phospho-S880 on GluR2 subunits in hippocampal neurons, which can remove GluR2 from the cell surface [36]. Another study found GluR2/3 trafficking and activity of Src kinase in the IR condition [37]. In the $15 \mathrm{~min}$ of global ischemia model followed by $0.5 \mathrm{~h}, 4 \mathrm{~h}$, and $24 \mathrm{~h}$ of reperfusion, Zhang et al. found that Src kinase was activated as a core glutamate receptor kinase after IR injury in GluR2/3 [37]. Additionally, GluR2/3 trafficking was related to the phosphorylation site S880, which was significantly up-regulated after IR injury. By contrast, inhibition of Src kinase protects the brain from ischemic injury. Such studies are few, but they do lend supporting evidence of changes to pGluR2 subunits at S880 during propofol post-conditioning, and the trafficking of AMPARs. In our study we showed that S880 was phosphorylated during IR injury, while propofol $(20 \mathrm{mg} / \mathrm{kg} / \mathrm{h})$ reduced the phosphorylation level of GluR2, which might contribute to the stabilization of AMPARs on neuronal surfaces. Our results also demonstrated that the prevention of both trafficking and phosphorylation of GluR2 subunits caused by propofol can be reversed by LY294002, which suggested that PI3K may be the upstream signaling pathway of GluR2 subunits and responsible for the trafficking and phosphorylation of GluR2. The limitation of the current experiment is that we haven't study the relationship and consequence between the phosphorylation of GluR2 and trafficking of this subunit, which means the change of GluR2 trafficking when the phosphorylation of GluR2 was blocked.

\section{PI3K and its regulating role of GluR2 subunits}

In 1985, PI3 kinases were first identified by Lewis Cantley and his colleagues, and were shown to be capable of phosphorylating the $3^{\prime}$ hydroxyl group of the inositol ring of phosphatidylinositol (PtdIns) to produce the novel phosphoinositide PtdIns(3,4,5)P3 from PtdIns(4,5)P2 [38]. The PI3K/AKt pathway plays an important role in protecting the brain from a lot of disorders such as ischemia, hypoxia, and free radical induced oxidative stress. The PI3K/Akt pathway is well known for its involvement in synaptic plasticity, and memory consolidation although the relationship between PI3K and long-term potentiation (LTP) is still debated. Among them, protein synthesis and
AMPAR insertion in late-phase LTP requires activation of the PI3K pathway. And the activation of the PI3K pathway also takes effect for the maintenance of LTP in hippocampal CA1 neurons [39]. Consistent with its important role in LTP, the PI3K-Akt pathway is also known to induce protein synthesis and AMPAR membrane translocation [40], and previous studies have found that the PI3K/Akt pathway plays a crucial role in the post-conditioning provided by propofol [3]. Other studies support the positive role of PI3K in the indirect trafficking of AMPARs [41], since inhibition of PI3K in neurons reduced the GluR2 surface expression. Moreover, depletion of PIKE (phosphoinositide 3-kinase enhancer), which directly interacts and enhances the activity of PI3K and Akt, reduced the activity of GluR2-associated PI3K, and thereby reduced GluR2 surface retention. Arendt et al. [11] concluded that the continuous low expression of PIP (3), which is the product of PI3K at the postsynaptic terminal, is necessary for the stabilization of AMPARs. Consequently, the activity of PI3K is vitally important to the stable expression of GluR2 at the postsynaptic terminal. In our current research, we discovered that enhanced complexes between PI3K and AMPARs GluR2 subunits played a critical role in the post-conditioning provided by propofol, and the trafficking of GluR2 to the plasma membrane of neurons during the protection, while the total expression of GluR2 subunits did not change a lot. The trafficking of GluR2 subunits was regulated by PI3K, for which the addiction of LY294002 would weaken the location of GluR2 subunits on the cytomembrane and postsynaptic membrane.

Our co-immunoprecipitation results showed that PI3K, which consists of both a catalytic (p110) and a regulatory (p85) subunits [42], enabled connection of the GluR2 subunits via the $\mathrm{p} 85$ subunits, which was concordant with the previous observation for LTP, wherein PI3K connected with GluR2 subunits by the C-terminal [12].

\section{Conclusions}

Propofol post-conditioning at $20 \mathrm{mg} / \mathrm{kg} / \mathrm{h}$ for $2 \mathrm{~h}$ significantly increases the frequency of GluR2 subunits in the postsynaptic membrane of neurons and reduces the levels of phosphorylation. Additionally, the protection and changes to the status of PI3K-GluR2 can be reversed partly by the inhibitor of PI3K, LY294002. In consideration of the trafficking and the change of pGluR2 subunits partly depend on the activity of PI3K, we inferred that the propofol post-conditioning protection may triggered by the activation of PI3K and achieved by the transport of GluR2 subunits to the postsynaptic membrane as well as the lower level of phosphorylation. This conclusion can better guide the clinical application of propofol. 
The limitation of the current experiment was that is did not study the relationship and consequence between the phosphorylation of GluR2 and the trafficking of this subunit. Furthermore, the role of AMPARs GluR2 subunit which accumulated on the membrane of intracellular organelles, such as lysosomes, mitochondria, and Golgi Complexes should be addressed in our future work.

\begin{abstract}
Abbreviations
AMPAR: amino-3-hydroxy-5-methylisoxazole-4-propionic acid receptor; PI3K: phosphoinositide-3-kinase; GluR: glutamate receptor; MCAO: middle cerebral artery occlusion; bFGF: fibroblast growth factor; Akt: protein kinase B; mNSS: modified neurological severity score; TTC: triphenyltetrazolium chloride; LTP: long-term potentiation; LTD: long-term depression; Ptdlns3P: phosphoinositide-3,4,5-trisphosphate; PDZ: protein 95/discsslarge/zon occlusens-1; S880: serine 880; Ptdlns: phosphatidylinositol; PIKE: phosphoinositide 3-kinase enhancer; pGluR: phosphorylated glutamate receptor; IR: ischemia-reperfusion.
\end{abstract}

\section{Acknowledgements}

Not applicable.

\section{Authors' contributions}

CW, Y Yu and GW conceived the project plan. CW, YW, Y Yuan planned, performed, and analyzed the experiments. KX, BD and YS collated and analyzed the data. CW wrote the manuscript and all authors discussed, modified and approved the final version. GW initiated and supervised the project. All authors read and approved the final manuscript.

\section{Funding}

This work was supported by Natural Science Foundation of China (81501013), Tianjin Medical University General Hospital Incubation Foundation (ZYYFY2015024). The funders played an important role in the design of the study and collection, analysis, and interpretation of data and in writing the manuscript.

\section{Availability of data and materials}

The datasets generated during the current study are available from the corresponding author on reasonable request.

\section{Ethics approval and consent to participate}

The experimental procedures in this study were approved by the Ethics Committee for Animal Experimentation of the Medical University of Tianjin, China (Aecl2015-0158 [JIN]).

\section{Consent for publication}

Not applicable.

\section{Competing interests}

The authors declare that they have no competing interests.

\section{Author details}

${ }^{1}$ Department of Anesthesiology, Tianjin Institute of Anesthesiology, General Hospital of Tianjin Medical University, No. 154 Anshan Road, Heping District, Tianjin 300052, People's Republic of China. ${ }^{2}$ Department of Anesthesiology, Tianjin People's Hospital, Tianjin Union Medical Center, Tianjin 300191, China.

Received: 2 January 2019 Accepted: 13 September 2019

Published online: 01 October 2019

\section{References}

1. Wang H, Li P, Xu N, Zhu L, Cai M, Yu W, Gao Y. Paradigms and mechanisms of inhalational anesthetics mediated neuroprotection against cerebral ischemic stroke. Med Gas Res. 2016;6(4):194.
2. Flower $\mathrm{O}$, Hellings S. Sedation in traumatic brain injury. Emerg Med Int. 2012;2012:637171.

3. Wang HY, Wang GL, Yu YH, Wang Y. The role of phosphoinositide-3-kinase/Akt pathway in propofol-induced postconditioning against focal cerebral ischemia-reperfusion injury in rats. Brain Res. 2009;1297:177-84.

4. Zhang Q, An R, Tian X, Yang M, Li M, Lou J, Xu L, Dong Z. beta-caryophyllene pretreatment alleviates focal cerebral ischemia-reperfusion injury by activating PI3K/Akt signaling pathway. Neurochem Res. 2017:42(5):1459-69.

5. Chang CP, Liu YF, Lin HJ, Hsu CC, Cheng BC, Liu WP, Lin MT, Hsu SF, Chang $L S$, Lin KC. Beneficial effect of astragaloside on Alzheimer's disease condition using cultured primary cortical cells under beta-amyloid exposure. Mol Neurobiol. 2016;53(10):7329-40.

6. Soundarapandian MM, Tu WH, Peng PL, Zervos AS, Lu Y. AMPA receptor subunit GluR2 gates injurious signals in ischemic stroke. Mol Neurobiol. 2005;32(2):145-55.

7. Landucci E, Filippi L, Gerace E, Catarzi S, Guerrini R, Pellegrini-Giampietro DE. Neuroprotective effects of topiramate and memantine in combination with hypothermia in hypoxic-ischemic brain injury in vitro and in vivo. Neurosci Lett. 2018;668:103-7.

8. Wright A, Vissel B. The essential role of AMPA receptor GluR2 subunit RNA editing in the normal and diseased brain. Front Mol Neurosci. 2012;5:34.

9. Mahajan SS, Thai KH, Chen K, Ziff E. Exposure of neurons to excitotoxic levels of glutamate induces cleavage of the RNA editing enzyme, adenosine deaminase acting on RNA 2, and loss of GLUR2 editing. Neuroscience. 2011;189:305-15.

10. Lohmann C, Kessels HW. The developmental stages of synaptic plasticity. J Physiol. 2014;592(1):13-31.

11. Arendt KL, Royo M, Fernandez-Monreal M, Knafo S, Petrok CN, Martens JR, Esteban JA. PIP3 controls synaptic function by maintaining AMPA receptor clustering at the postsynaptic membrane. Nat Neurosci. 2010;13(1):36-44

12. Man HY, Wang Q, Lu WY, Ju W, Ahmadian G, Liu L, D'Souza S, Wong TP, Taghibiglou C, Lu J, et al. Activation of PI3-kinase is required for AMPA receptor insertion during LTP of mEPSCs in cultured hippocampal neurons. Neuron. 2003;38(4):611-24.

13. Famous KR, Kumaresan V, Sadri-Vakili G, Schmidt HD, Mierke DF, Cha JH, Pierce RC. Phosphorylation-dependent trafficking of GluR2-containing AMPA receptors in the nucleus accumbens plays a critical role in the reinstatement of cocaine seeking. J Neurosci. 2008:28(43):11061-70.

14. Liu F, McCullough LD. Middle cerebral artery occlusion model in rodents: methods and potential pitfalls. J Biomed Biotechnol. 2011;2011:464701.

15. Lee YS, Chio CC, Chang CP, Wang LC, Chiang PM, Niu KC, Tsai KJ. Long course hyperbaric oxygen stimulates neurogenesis and attenuates inflammation after ischemic stroke. Mediat Inflamm. 2013;2013:512978.

16. Alibrahim A, Zhao LY, Bae CY, Barszczyk A, Sun CL, Wang GL, Sun HS. Neuroprotective effects of volume-regulated anion channel blocker DCPIB on neonatal hypoxic-ischemic injury. Acta Pharmacol Sin. 2013;34(1):113-8.

17. Wang H, Luo M, Li C, Wang G. Propofol post-conditioning induced longterm neuroprotection and reduced internalization of AMPAR GluR2 subunit in a rat model of focal cerebral ischemia/reperfusion. J Neurochem. 2011;119(1):210-9.

18. Yang XY, Stanley RE, Ross AP, Robitaille AM, Gray JA, Cheyette B: Sestd1 encodes a developmentally dynamic synapse protein that complexes with BCR Rac1-GAP to regulate forebrain dendrite, spine and synapse formation. CEREB CORTEX 2017.

19. Adotevi NK, Leitch B. Synaptic changes in AMPA receptor subunit expression in cortical parvalbumin interneurons in the stargazer model of absence epilepsy. Front Mol Neurosci. 2017;10:434.

20. Sonomura T, Furuta T, Nakatani I, Yamamoto Y, Unzai T, Matsuda W, I wai H, Yamanaka A, Uemura M, Kaneko T. Correlative analysis of immunoreactivity in confocal laser-scanning microscopy and scanning electron microscopy with focused ion beam milling. Front Neural Circuits. 2013;7:26.

21. Traynelis SF, Wollmuth LP, McBain CJ, Menniti FS, Vance KM, Ogden KK, Hansen KB, Yuan H, Myers SJ, Dingledine R. Glutamate receptor ion channels: structure, regulation, and function. Pharmacol Rev. 2010;62(3):405-96.

22. Wu D, Bacaj T, Morishita W, Goswami D, Arendt KL, Xu W, Chen L, Malenka RC, Sudhof TC. Postsynaptic synaptotagmins mediate AMPA receptor exocytosis during LTP. Nature. 2017;544(7650):316-21. 
23. Fujii S, Tanaka H, Hirano T. Detection and characterization of individual endocytosis of AMPA-type glutamate receptor around postsynaptic membrane. Genes Cells. 2017;22(6):583-90.

24. Han XJ, Shi ZS, Xia LX, Zhu LH, Zeng L, Nie JH, Xu ZC, Ruan YW. Changes in synaptic plasticity and expression of glutamate receptor subunits in the CA1 and CA3 areas of the hippocampus after transient global ischemia. Neuroscience. 2016;327:64-78.

25. Xu Y, Xue H, Zhao P, Yang Y, Ji G, Yu W, Han G, Ding M, Wang F. Isoflurane postconditioning induces concentration- and timing-dependent neuroprotection partly mediated by the GluR2 AMPA receptor in neonatal rats after brain hypoxia-ischemia. J Anesth. 2016;30(3):427-36.

26. Liu SJ, Zukin RS. Ca2 +-permeable AMPA receptors in synaptic plasticity and neuronal death. Trends Neurosci. 2007:30(3):126-34.

27. Tang XJ, Xing F. Calcium-permeable AMPA receptors in neonatal hypoxicischemic encephalopathy (Review). Biomed Rep. 2013;1(6):828-32.

28. Medvedeva YV, Lin B, Shuttleworth CW, Weiss JH. Intracellular Zn2 + accumulation contributes to synaptic failure, mitochondrial depolarization, and cell death in an acute slice oxygen-glucose deprivation model of ischemia. J Neurosci. 2009;29(4):1105-14.

29. Krishnamurthy K, Mehta B, Singh M, Tewari BP, Joshi PG, Joshi NB. Depalmitoylation preferentially downregulates AMPA induced Ca2+ signaling and neurotoxicity in motor neurons. Brain Res. 2013;1529:143-53.

30. Liu K, Lei R, Li Q, Wang XX, Wu Q, An P, Zhang J, Zhu M, Xu Z, Hong Y, et al. Transferrin receptor controls AMPA receptor trafficking efficiency and synaptic plasticity. Sci Rep. 2016;6:21019.

31. Ishida K, Kotake Y, Sanoh S, Ohta S. Lead-induced ERK activation is mediated by GluR2 non-containing AMPA receptor in cortical neurons. Biol Pharm Bull. 2017;40(3):303-9.

32. Chan CB, Chen Y, Liu X, Tang X, Lee CW, Mei L, Ye K. PIKE-mediated PI3kinase activity is required for AMPA receptor surface expression. EMBO J. 2011;30(20):4274-86

33. Yu Y, Huang Z, Dai C, Du Y, Han H, Wang YT, Dong Z. Facilitated AMPAR endocytosis causally contributes to the maternal sleep deprivationinduced impairments of synaptic plasticity and cognition in the offspring rats. Neuropharmacology. 2018;133:155-62.

34. Wang Y, Wei W, Song B, Wang Y, Dong J, Min H, Chen J. Developmental hypothyroxinemia caused by mild iodine deficiency leads to
HFS-induced LTD in rat hippocampal CA1 region: involvement of AMPA receptor. Mol Neurobiol. 2014;50(2):348-57.

35. Bakshi K, Kosciuk M, Nagele RG, Friedman E, Wang HY. Prenatal cocaine exposure increases synaptic localization of a neuronal RasGEF, GRASP-1 via hyperphosphorylation of AMPAR anchoring protein, GRIP. PLOS ONE. 2011;6(9):e25019.

36. Liu SJ, Gasperini R, Foa L, Small DH. Amyloid-beta decreases cell-surface AMPA receptors by increasing intracellular calcium and phosphorylation of GluR2. J Alzheimers Dis. 2010;21(2):655-66.

37. Zhang F, Guo A, Liu C, Comb M, Hu B. Phosphorylation and assembly of glutamate receptors after brain ischemia. Stroke. 2013;44(1):170-6.

38. Auger KR, Serunian LA, Soltoff SP, Libby P, Cantley LC. PDGF-dependent tyrosine phosphorylation stimulates production of novel polyphosphoinositides in intact cells. Cell. 1989;57(1):167-75.

39. Choi JH, Park P, Baek GC, Sim SE, Kang SJ, Lee Y, Ahn SH, Lim CS, Lee YS, Collingridge GL, et al. Effects of PI3Kgamma overexpression in the hippocampus on synaptic plasticity and spatial learning. Mol Brain. 2014;7:78.

40. Gobert D, Topolnik L, Azzi M, Huang L, Badeaux F, Desgroseillers L, Sossin WS, Lacaille JC. Forskolin induction of late-LTP and up-regulation of $5^{\prime}$ TOP mRNAs translation via mTOR, ERK, and PI3K in hippocampal pyramidal cells. J Neurochem. 2008;106(3):1160-74.

41. Engelhard K, Werner C, Hoffman WE, Matthes B, Blobner M, Kochs E. The effect of sevoflurane and propofol on cerebral neurotransmitter concentrations during cerebral ischemia in rats. Anesth Analg. 2003;97(4):1155-61.

42. Feola A, Cimini A, Migliucci F, lorio R, Zuchegna C, Rothenberger R, Cito L, Porcellini A, Unteregger G, Tombolini V, et al. The inhibition of p85alphaPI3KSer83 phosphorylation prevents cell proliferation and invasion in prostate cancer cells. J Cell Biochem. 2013;114(9):2114-9.

\section{Publisher's Note}

Springer Nature remains neutral with regard to jurisdictional claims in published maps and institutional affiliations.
Ready to submit your research? Choose BMC and benefit from:

- fast, convenient online submission

- thorough peer review by experienced researchers in your field

- rapid publication on acceptance

- support for research data, including large and complex data types

- gold Open Access which fosters wider collaboration and increased citations

- maximum visibility for your research: over $100 \mathrm{M}$ website views per year

At BMC, research is always in progress.

Learn more biomedcentral.com/submissions 